\title{
Tiromoana and Taranaki House: A tale of their times
}

Barbara Staniforth

Dr Barbara Staniforth is a Senior Lecturer in the School of Counselling, Human Services E Social Work at Auckland University. She can be contacted at b.staniforth@auckland.ac.nz.

\section{Introduction}

The overall history of social work education in Aotearoa New Zealand has been well documented by authors such as McCreary (1971a,b), Nash (1998) and Cranna (1989). Tiromoana and Taranaki House social work residential training institutions were set up by the Education Department, Child Welfare Division to meet a gap in social work training in the country in the 1960s and 70s. These programmes, which were at times contentious, appeared to be unique and particular to their time, place and context in Aotearoa New Zealand.

This article provides some history and participant recollections about Tiromoana (Porirua) and Taranaki House (Auckland) for social work's historical record. This article attempts to piece together various sources, including recent interviews, and to weave together some of the facts and stories of these two institutions.

\section{Methodology}

This research comes from a constructivist position, recognising the structural, cultural and historical factors that go into writing a particular version of a history. The Project was given ethics approval from the University of Auckland Human Participants Ethics Committee in October 2013.

A literature review was undertaken and came up with four articles directly related to the Programmes, written between 1968 and 1973, (Mann, 1964; de la Roche, 1971; Austin, 1973, Manchester, 1973) and some material from dissertations such as Nash (1998). Information was also obtained from the files of Archives New Zealand (mainly correspondence) and a very limited amount of information also came from the Alexander Turnbull Library.

Information and an invitation to participate in the study were sent via email to members of Aotearoa New Zealand Association of Social Work (ANZASW), with 37 people indicating interest in the study. Five other people were approached due to their known association with one or both of the programmes. Of those 42 people, six provided information via email, and 16 were interviewed either via Skype, telephone or in person, between November 2013 and September of 2014. Participants were given the opportunity to be named or remain anonymous, and all participants reviewed their contributions prior to publication. One person decided that they did not want to proceed after they had been interviewed. Two sets of course notes and other material were provided by Wendy Cruse and posthumously from Bertha Zurcher. 
This is by no means a complete account of these institutions. Voices of Māori and Pasifika persons are not well represented in this work, nor has an exhaustive archival search been done. There is room for much further study and documentation in these areas. As in any writing, there are many versions of history. The voices of some trainees and tutors have been privileged here, but there are many other people associated with the programmes who will have had different accounts and stories.

\section{Context of the development of Tiromoana and Taranaki House}

While a conference of the Education Department decried a need for formal social work training in New Zealand in 1943 (New Zealand Council for Educational Research, 1944), the first recognised social work training programme did not begin until 1949-1950 with the beginning of the Post Graduate Diploma in Social Science offered through Victoria University in Wellington (See McCreary $(1971 a, b)$ for a detailed account of the history contributing to the inception of the School and the first 20 years of its programmes). Until the establishment of Massey University and University of Canterbury social work programmes in 1976 Victoria University's PGDip in Social Science was the only professional qualification offered in Aotearoa New Zealand.

The 1960s-1970s was a time of rapid growth for the profession of social work, with the New Zealand Association of Social Workers being founded in 1964 and joining the International Federation of Social Workers in that same year (Beddoe and Randal, 1994). While many people who were essentially 'doing' social work had previously identified with their area of work (e.g. child welfare officers, visiting teachers and probation officers), statutory and non-government workers were starting to identify themselves as social workers, and it was clear that very few had had formal training in the field (Nash, 2001). While the Victoria Programme had begun the process of a qualification for social work, it could in no way meet the educational and training needs of the growing sector with only a limited number of graduates being produced each year. ${ }^{1}$ One of the major institutions requiring training for its workers was the Education Department, Child Welfare Division.

Brian Manchester detailed this period in his 2008 book, describing the Social Science Cadetship and Social Work Trainee schemes that had been in place since the late 1950s. Manchester was appointed as Senior Boys' Welfare Officer in the Child Welfare Division of the Department of Education in 1959 and some time later, as part of the Social Science Advisory Committee, he was asked to develop plans for a 'short term full time' (p. 100) social work training programme:

I developed a concept of eight weeks of full time training to be taken in two blocks of four weeks each with a six week pause between the two teaching blocks. My rationale for this...was that fieldwork pressures in our district offices were such that a four week absence was as long as the staff member could be away from their caseload without causing inordinate difficulty... Another factor was that so many officers had personal and family commitments which made it difficult for them to be away for extended periods (pp. 100-101).

1 Nash (1998) also describes the Certificate in Theory of Social Work and the Certificate in Theory and Practice of Social Work offered through the Interim Board of Studies of NZASW in Christchurch, Auckland and Wellington. 


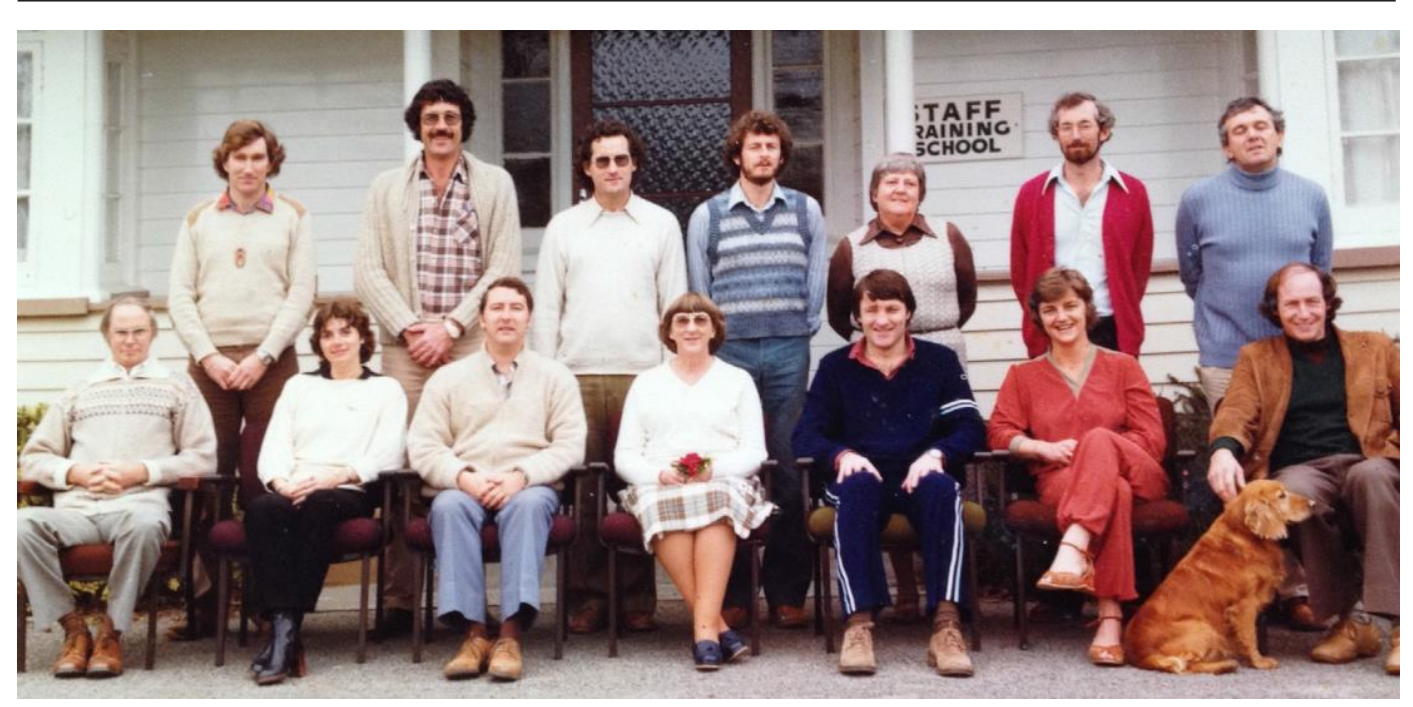

Staff from the three DSW training centres: Tiromoana , Taranaki House and Kohitere, circa 1976-77, Back: ?; Sandy Rennie; ?; Lester Mundell; Joan Donald; John Crockett; Jeff Thomas.

Front: Tony Pennell; Allyson Davies; John Groom; Agnes Brabin; Graham Harbutt; Tanya Cumberland; Alan Birrell.

Manchester planned for a course that would include pre-course reading and practical work that would be conducted during the six-week break between courses, thus allowing for the beginning of integration of theory and practice. The State Services Commission accepted Manchester's proposal and he detailed his quest for accommodation for the programme. Geoffrey Blake-Palmer, who was at the time Director of Mental Health, indicated that there was a Truby King villa on the grounds of Porirua Hospital which had previously served as a ward for psychiatric patients who had tuberculosis. Upon inspection Manchester indicated that, '...the building was basically sound - full of birds' nests and with fresh air flowing freely from many vents as consistent with notions of treating TB' (p. 101). Dr Blake-Palmer then undertook to prepare the building for purpose under his hospital maintenance budget.

Manchester drew up a proposed curriculum in consultation with various people, which he then put to other members of the sub-committee, Professor Minn from the Victoria University social science programme and Dr Geoffrey Blake-Palmer. 'The courses were intended to be open to Child Welfare Officers, Probation Officers, Māori Welfare Officers, Social Security Social Workers, Public Health Nurses of the Department of Health, Medical Social Workers from Hospital Boards, and visiting teachers employed by Education Boards' (2008, p. 102). After careful lobbying of Norman Angus (then Superintendent of Staff Training, State Services Commission) at the New Zealand Association of Social Workers conference in Auckland in 1964, he agreed that places on these courses would also be made available on a modest scale to social workers from voluntary social work services (B. Manchester, personal communication, 3/12/14).

Manchester had been instrumental in the development of the Programme, but he had no interest in leading it. The role of director was fi taken by Tom Austin, who, in 1962 came from Probation for the fi intake of social workers onto the 'Induction Training' (Austin, 1973). 
The Programme was named Tiromoana, in Māori meaning 'view of the sea', as the buildings on the Porirua Hospital grounds, which housed the programme, looked over the ocean (Mann, 1964). Ruth Manchester was initially a tutor at Tiromoana and later returned as Director in 1970. She described Tiromoana as:

A single story building with a large teaching room at the north end which could be divided into two rooms by a folding partition, and having an enclosed verandah which gave access to a number of single accommodation rooms linking the main teaching room to the main entrance where the kitchen and dining room were located together with the offices of the Director and Secretary. In the south wing there were 10-12 rooms on both sides of the corridor. In the early 1970s a 'Lockwood' pre-fabricated type house was built at the rear of the main building with enclosed connection to it. This provided four more accommodation rooms for course members and some office accommodation for tutors, and provided for the Library thereby leaving the former library room available for tutorials and small group meetings. These changes meant that Tiromoana could quite adequately accommodate and cater for residential courses of up to twenty members (R. Manchester, personal communication, 17/11/13).

The Department of Education, Child Welfare Division, administered Tiromoana from its establishment in 1963 until 1 April 1972, when its operation and management passed to the newly established Department of Social Welfare (DSW). At that time the backgrounds of course members changed. Up to 1973, course members were Child Welfare Officers, Probation Officers, Māori Welfare Officers, Medical Social Workers from Hospital Boards, and social workers from voluntary welfare agencies. The only two groups that had 'social worker' in their designation were Medical and Psychiatric Social Workers most of whom had a nursing background. From 1973 Public Health Nurses and visiting teachers no longer sought this form of training, leading to a shift in the occupational makeup and therefore training needs of participants:

The background of course members in those earlier years played an on-going part in the development of the courses offered. Most members of Government Departments attending the courses saw themselves as public servants or 'officers' following prescribed departmental roles and regulations. The programmes for the earlier courses took this into account (R. Manchester, personal communication, 16/05/14).

Tiromoana became well established and was in demand through the 1960s with people being required to travel very long distances to attend. At this time there was no formal training opportunity to service the large number of social workers in the Auckland and Northern regions. Brian Manchester, who in 1973 sat on the Social Work Training Council, was on the Induction Training for Social Workers Sub Committee, which was tasked with the responsibility of setting up 12-week courses for newly appointed social workers:

A major aspect of setting up the twelve week training programmes was the establishment of Taranaki House Social Work Training Centre in Auckland. Taranaki House consisted of two quite large single $\mathrm{fl}$ wooden-buildings situated on either side of the main driveway into Avondale College in Auckland. Avondale College had, I understand, been taken over as a fi hospital for the American Pacifi Forces during World War II. The buildings known as Taranaki House had been constructed as a Nurses Home for the Hospital. In post war years they had been used as hostel accommodation for students, mainly from Taranaki, attending Auckland Teachers' College - hence the origin of the name 'Taranaki House' (Manchester, 2008, p. 260). 
The premises were leased from the Department of Education for a token rent, and Taranaki House opened in 1974. Initial tutor help was provided for a short time from Continuing Education at The University of Auckland, with Gordon Dawber as the first appointed Director (Manchester, 2008).

\section{Induction courses}

The structure and content of the Tiromoana induction courses shifted over the time that the programmes ran. The four-week, six-week break, four-week structure remained for quite some time. When one group finished the first four weeks, there would be a break of a week, and then another group would begin their first four weeks (Austin, 1973). Ruth Manchester described the largely unchanging structure of the courses over time:

From being set up in 1963, until I left in 1976, the annual time format for the courses was essentially the same - four eight week courses taken in two periods of four weeks with a six week break between. Course members were required to bring to the second half a case study they had prepared from their own work setting which was discussed individually with a Tiromoana staff member and also in a small group setting with other course members. ... The time structure of these courses remained essentially the same until I left in 1976 apart from establishment in 1974 of a three month course designed to ensure that newly appointed social workers could be given opportunity of some initial training immediately following recruitment and before taking up the social work position to which they had been appointed (R. Manchester, personal communication, 16/05/14).

The format of Taranaki House's induction training also shifted over time. Tanya Cumberland described that the 'first courses were three months full-time residential courses which posed challenges for students and staff. This later changed to two weeks, with a six-week gap, then two weeks back' (T. Cumberland, personal communication, 8/09/14).

From the beginning, training at Tiromoana emphasised a self-reflective quality to the learning. Norma Mann, a nurse, described her time in the first course ever run at Tiromoana:

A nurse at post-graduate level would find subjects such as Human Growth and Behaviour, Social and Psychological Problems, and Health and Disease not new to her, but the manner of presentation of these subjects was rather different at Tiromoana. In the discussion periods following sessions on Human Growth and Behaviour and, more subtly, following sessions on Social and Psychological Problems, discussions were steered from 'the world in general' to ourselves. We discussed our personal experiences, the 'how' and 'why' of our own behaviour. These were not always 'comfortable' sessions, but they gave us all something to think about (Mann, 1964, p. 13).

Austin described how during his time at Tiromoana the method of teaching was based on '...teaching in small groups, on discussion and on course member involvement and contribution. To a fair degree it was a shared enterprise between tutors and students' (1973, p. 5). Mann also noted that in the period of the six-week break between the course blocks, '... students were required to write up a case study of a client under supervision for presentation during the second month' (1964, p. 13).

Ruth Manchester described that, '...in the 1960s the focus was on outside speakers presenting sessions about Government Departments and voluntary agencies which provid- 
ed social/administrative services in the widest sense' (R. Manchester, personal communication 16/05/14). Due to the programme being repeated through the year, many of these speakers would become regular returnees. Manchester also discussed the use of films and other teaching resources:

We used educational films (mostly from Canada), often for evening sessions. These were obtained from the National Film Library in Wellington and were in the form of big reels stored in round tin boxes (R. Manchester, personal communication, 17/11/13).

Manchester also detailed some of the shifts in the focus on training at Tiromoana between 1966 and 1973:

We have now moved some way from the former emphasis on the one-to-one method of case-work to a growing emphasis on group work, family counselling, community work, social action and a concern for contemporary social issues aff our total way of life (R. Manchester, 1973, p. 7).

Garry Cockburn, who attended Tiromoana in 1974, recalled that:

...the teaching course covered the major things we needed to know as new social workers, e.g. legislation, family court processes, administrative requirements, such as 'placement slips' when a child moved house, plus the opportunity to meet senior staff at Head Office, such as Brian Manchester, etc (G. Cockburn, personal communication, 14/02/14).

In the 1960s, education was often integrated with developing self-awareness. Through the late 1960s and early 1970s, New Zealand was influenced by the Encounter Movement (learning about oneself through processing interactions with others) which came out of California. Group work was process oriented with emphasis placed on self-exploration and personal growth. This period is addressed further later in the article on the theme of vulnerability, but until the 1980s, this form of learning permeated much of Tiromoana and Taranaki House training.

Many participants commented on the usefulness of the focus on personal growth and awareness. David Burrowes, who attended Tiromoana in 1974, remembered that the 'personal growth and development was useful to me. I learned about the influence of values and how they impacted on your actions working with people' (D. Burrowes, personal communication, 24/01/14). Liz Beddoe, who attended Taranaki House in 1978, remembered that:

We learned Carkuff and basic counselling skills. Some of the best skills training I ever had. Interpersonal skills. Well taught. Lots of practice. Small group work skills, goldfish bowl. Tutors skilled at getting us to be brave, got us to do lots of work that may have been confronting. It was good personal development (L. Beddoe, personal communication, 21/01/2014).

Sometimes the attention to process could be quite an intense and time-consuming endeavour. Peter Pascoe who was a tutor at Taranaki House between 1977 and 1979 describes an example of this:

When people arrived the first morning, it was getting to know you, ground rules. Dealing with the smoking issue would take up to three hours. We never got a clear direction from Head Office. Then in later years it was a given that there was no smoking in groups (P. Pascoe, personal communication, 20/01/14). 
The intensity of work that went on within the two programmes was often commented upon. This was partly due to content and processing, but it also had to do with the long hours and the residential nature of the programme that took the work well into the evening hours. 'While residential was intense, it also meant at the end of the day we went into social connection with people. Intensity and relationships facilitated the training being effective as it built up trust' (L. Beddoe, personal communication 21/01/14). Another respondent remembered that there was, ' ... a lot of evening discussion that went on in smaller groups, late nights, processing some of the stuff that went on in the day' (Anonymous), while another person remembered 'that the days were quite long and we worked hard and were expected to pull our weight in discussions etc.' (Anonymous).

Pascoe remembered a shift in the climate of the structure and content of courses during his tenure as tutor at Taranaki House:

Gordon, the first director, took the course in particular directions.... Because Taranaki House took people from various places, they wanted a generic model, so there was no time to focus on skill development. Focus was on self-development. It was really exciting, like working in long-term encounter group. Gordon left after a year and Tanya [Cumberland] became director. She wanted a more skills based approach. We did more direct skills development and information giving. ... Over time the format changed. Initially there was a block of 12 weeks. Students went out on visits, did placements, a three day trip to Marae. Under Tanya we took people in smaller blocks, 5 weeks, 5 weeks, 2 weeks, Nobody knew how to do it. The idea was to put more focus on workplace, do case studies, which they hadn't done before. People were expected to bring case studies back with them, do homework. Big shift. Very appropriate (P. Pascoe, personal communication 20/01/14).

A brochure for the Induction Programme (circa 1980) at Taranaki House includes the 'Objectives and Opportunities' for the Course:

1. To explore the social work task and its value base.

2. To understand one's personal resources in relation to the social work task.

3. To develop skills in interviewing, with an emphasis on problem solving.

4. To learn the theory and practice of some social work methods.

5. To explore cross-cultural issues related to social work.

6. To prepare a management plan for ongoing professional development.

7. To visit a range of community resources.

(Taranaki House, Training for Social Work, Induction Course, p. 2).

Allyson Davys, tutor at Taranaki House from 1979-1984, remembered that learning took various forms in her time there:

We had fun. I learnt that learning and education can be fun. We played lots of interactive games, often needed to change the energy when you have sustained interaction with the same group. Lots of fun and energy (A. Davys, personal communication, 31/01/14).

Wendy Cruse attended Tiromoana in 1983. Her induction notes from that time include a range of theoretical material, skills training and field visits. Structure for this induction course was three weeks on course, four months off, two weeks back (see Table one for course structure). One of the main components of training also involved field trips. 
Table one. Course content Tiromoana Induction 1983.

The social work task

The social work role

Policy

Introduction to societies, communities, social policy

Cross cultural issues in social work
Systems theory and social work

Video in work groups

Marae visit (scheduled, but did not occur)

Human development

Debate of issue of policy or ethics

Supervision: Its role and function in professional social work.

Communication patterns for individual, groups \& families

Multiple skills workshops management and skills (Assessment, intervention, termination)

Tools for administration Stress management Goal setting and relaxation

Skills for public presentation (public speaking, debating, presenting reports)
Personal and professional goal setting
Putting it all together

Introduction to family work.

\section{Fieldtrips}

Induction programmes at both Tiromoana and Taranaki House included visits to local agencies as a regular component of training (see Table two for an example of some of the agencies that were visited from Tiromoana in 1983). David Burrowes discussed one of the more memorable evening visits that occurred on his training programme from Tiromoana in 1974:

We went on field trips. One was to the Purple Onion in Wellington. Carmen's establishment. [Referring to a strip club run by one of Wellington's colourful proprietors]. This was part of our 'Sexual Deviation Module'. Quite a number of people went, some of the women as well (D. Burrowes, personal communication, 24/01/14).

This was corroborated by another Tiromoana participant who found a sheen of glitter on his suit the following day.

Tiromoana visits in the earlier days often involved Porirua Hospital. This provided an intensive education on mental health symptoms and treatment and included, for some trainees, an observation of an ECT session:

I remember a visit to Porirua Hospital where we observed a woman having ECT, which I found very distressing. I do not believe we were prepared well for this. I did not really understand what we were to see. I have no idea whether the woman gave consent for a group of us to witness this procedure, or whether she was, at the time, competent to give consent. This single event is the one I most vividly remember from my time at Tiromoana (M. Farrelly, personal communication $11 / 11 / 13$ ). 
Table two. Fieldtrips Tiromoana 1983.

$\begin{array}{lll}\begin{array}{l}\text { Multi-Cultural Resource } \\ \text { Centre, Wellington }\end{array} & \text { Arohata Prison } & \text { Inner City Ministry } \\ \text { Puketiro Centre } & \text { Kohitere Boys Home } & \text { Community Health Service } \\ \text { Ewart Hospital } & \text { Wi Tako } & \text { Todd Motors } \\ \text { Te Omanga Hospice } & \text { Miramar Girls Home } & \text { C.A.B. Porirua } \\ \text { Dr Barnardo's } & \text { Porirua Hospital } & \text { Unemployed Workers Union }\end{array}$

Hutt Hospital - Maternity and Paediatrics

Tiromoana visits in the earlier days often involved Porirua Hospital. This provided an intensive education on mental health symptoms and treatment and included, for some trainees, an observation of an ECT session:

I remember a visit to Porirua Hospital where we observed a woman having ECT, which I found very distressing. I do not believe we were prepared well for this. I did not really understand what we were to see. I have no idea whether the woman gave consent for a group of us to witness this procedure, or whether she was, at the time, competent to give consent. This single event is the one I most vividly remember from my time at Tiromoana (M. Farrelly, personal communication $11 / 11 / 13)$.

Sue Arnold, who was at Taranaki House in 1977, remembers visits to Paremoremo Prison, Betty Wark in the community, ${ }^{2}$ and having sessions with Pita Sharples and staying over at a marae in Tuakau (S. Arnold, personal communication, 20/10/14). Other sessions saw students visit the Pacific Islanders Educational Resource Centre in Herne Bay, Auckland and stay over at a marae in Ahipara.

Graham Harbutt, who was tutor at Taranaki House from 1978 and then director from 1982 to 1985 , remembers that students would also have fi visits to Centrepoint ${ }^{3}$. 'We would send out students there on agency visits. They would spend an afternoon there on the basis that this was an alternative community. In 1982 we didn't do it anymore. Some of participants were not happy for having had to go there (G. Harbutt, personal communication, 31/01/14).

\section{Other programmes offered}

While Tiromoana and Taranaki House were set up initially to provide basic induction training for social workers, both would grow to offer other programmes. Ruth Manchester remembered the establishment of supervision training at Tiromoana:

\footnotetext{
${ }^{2}$ Betty Wark was manager of Ngati Arohanui Trust and worked with thousands of disadvantaged youth in the Auckand area from the 1960s until she died in 2001 (Johnston, 2001).

${ }^{3}$ Centrepoint was a commune established in Albany, New Zealand in 1978, based on the Encounter Group movement. Its founder, Bert Potter, and six other residents were convicted of indecent assault on minors and rape. Centrepoint was closed by the courts in 2000 (Government of New Zealand, n.d.).
} 
A two-week course for social work supervisors from statutory and voluntary agencies was presented from the end of 1965 and became an accepted feature of the annual programme of Tiromoana and later Taranaki House courses. The first social work supervision course was programmed and offered mainly by staff from the Department of Sociology and Social Work of Victoria University of Wellington. I taught on the initial course in 1965 and returned from my position in Dunedin to teach on the 1967 course. In the 1970s one or two week refresher courses were offered for staff with substantial years of experience who had not had any significant earlier training courses (R. Manchester, personal communication 16/05/14).

Available courses continued to expand in both programmes. Tanya Cumberland, Tutor at Taranaki House from 1975 to 1978 and then Director until 1981, described the various programmes that had developed at Taranaki House:

We had Induction, Supervision, Management, Training the Trainers... then we also did regional training. Taranaki House became a kind of hub for social work training and resources in the larger Auckland area....We also started taking training to the regions. We went to Hamilton and did 10 one-day courses for diff ent social work staff groups in residential and the offi (DSW). We also went to Rotorua, Whangarei and Kaikohe. They were really successful. Staff did the travel not the students. Then we had regional workshops and would also at times provide one off training for individual offi and at times would help offi with organisational issues.

See Table three for other courses offered at Taranaki House in 1980.

Sometimes outside trainers were brought in to help the teams and to contribute particular expertise to the programmes. Several participants in this study noted the management workshops by David Wright, Senior Manager at IBM in Wellington, which were run in 1979. Tanya Cumberland also described how Wright's expertise was further used as Taranaki House tutors were asked to help DSW offices with organisational or management issues (T. Cumberland, personal communication, 8/09/14).

Table three. Timetabled courses for Taranaki House, 1980.

Induction Courses

Regional Interdepartmental Workshop

Domestic Purposes Benefit Seminar

Skills of Interviewing Course

Planning for Children and Young People in Care

Basic Social Work Skills
Social Work Training Staff Meeting

Refresher Supervision and Management

Training for Trainers

Introduction to Supervision and Management

Child Abuse

Working with Families

Interview participants provided much information regarding the content of the courses they ran or attended. There were also some themes presented that crossed content, process and structure of the programmes. These included issues to do with people's sense of vulnerability in the programmes and sexual boundary issues (which were sometimes related to each other), and issues to do with biculturalism. These will be explored in the following section.

\section{Themes emerging from the interviews}

\section{Vulnerability}

Vulnerability of participants in the programmes was a theme that emerged in the interviews. 
There were a few strands to this theme. One revolved around the process focus on group work and the challenging and confronting interactions that sometimes went with this. Some of these challenges came from tutors or visitors, but many also came from other participants on the course. The degree to which confrontations were controlled by tutors appeared to vary. One Taranaki House participant recalls that they 'spent a lot of time picking up pieces of people, challenging people, about the group formulation and relationship with the tutors' (Anonymous).

Brian Manchester held the position of Chief Education and Training Officer, Head Office, DSW, between 1973 and 1978. He stated in his book that he often found himself having to justify some of the training methods being used in the programmes to others in his organisation, and indeed at times to himself:

It was understandable that coinciding with the Department's sudden development of a wide range of short courses in the mid-1970s and the recruitment of quite a number of social work tutors and teachers to offer them, the emphasis on group process, self discovery, self awareness, encounter techniques, sensitivity techniques, and interpersonal helping skills should permeate the Department's training programme as offered. It was not surprising that some training staff went too far. There were many times when I had to have some strong restraining words with some trainers, and even to exclude one of the two trainers from taking sessions on our courses (Manchester, 2008, pp. 272-273).

\section{A Tiromoana participant described their experience:}

One of the purposes of the course was to provide an opportunity for course members to examine their suitability for social work; thus there was a lot of 'navel gazing', and an encounter group feeling about many of the group activities. There was also a lot of sexual innuendo. I remember a lot of tears being shed by various participants, a lot of nasty unhelpful remarks being made by some group members, and staff, toward others, and some very unhappy group members leaving. The Christians in the group felt marginalized, formed an informal support group together, looked out for each other, and made a stand when their values were challenged. One had to be 'on guard' for one's own emotional/spiritual safety; it did not feel safe (Anonymous).

For some, the experiences were very significant in terms of personal and career development. 'We went away from home. It was difficult to talk about it with someone who had not been on the course. It was a life changing experience. Might have been difficult for people (D. Burrowes, personal communication, 24/01/14).

Allyson Davys recalled that by the time she was a Tutor at Taranaki house that:

We did not use encounter group methods, but rather encouraged and promoted self-awareness. This could trigger things for people. We made assumptions that people had the ability to look after themselves in those contexts, an expectation of robustness, but it didn't necessarily suit everybody. There always were group dynamics. Those people got to know themselves - self-awareness, better I think than we do now... (A. Davys, personal communication, 31/01/2014).

\section{Sexual boundaries}

One of the issues that came up time and again throughout the interviews was that of sexual activity and sexual boundary violations that had occurred through the training programmes. Some of this was attributable to people being away from home for long periods of time, in 
programmes that involved intense interpersonal process, self-disclosure and being together in the evenings when alcohol or other substances may have been consumed. At other times it appeared to be an abuse of power.

Garry Cockburn attended Tiromoana in 1974. He remembered the Programme's reputation had preceded his attendance and stated that a supervisor at a certain Child Youth and Family offi had stories about Tiromoana and sexual freedom that had gone on there.

There were rumours of social workers sharing rooms. It had changed by the time I got there. We were very proper. I remember going there with a sense of trepidation, nervousness. I didn't know what was going to happen, but retrospectively I found it useful (G. Cockburn, personal communication, 14/02/14).

One participant recalled that:

It was risky in terms of people being away from home... Especially people who were young, in a couple, and who had kids. Some people would sneak home to get back to see their kids. There was an emotional intensity of the relationships. Sexual relationships did happen, and for some people there were consequences of that in people's lives. It pushed people together in intense ways, they were closely located, and only went home on weekends. There was a lot of interaction... Risk for that (Anonymous).

Correspondence from Head Office at that time indicates that one of the 'solutions' to some of this activity was to allow spouses to 'live in' and at times even to be able to attend the courses:

During some earlier courses, I and yourself have received unfavourable comment about what you have described in one memo as 'sexual experimenting'. Although I am not so naïve as to believe that this has ended or can ever end entirely with residential courses, frequent visiting of spouses - and many have made day time visits - has coincided with an improved morale and ethical climate. On this course two young women and one young man have stayed overnight in their spouses' rooms. As with all official visitors they have paid the standard rate for all meals consumed, including breakfast. I am very much in favour of this arrangement, which has in no way detracted from the teaching programme. On some occasions spouses have attended teaching sessions, and this has in my view led to increased rapport and understanding between the couple about the implications of social work as a profession (G. Dawber, personal communication, 17/05/77).

What was more disconcerting for several people was the perceived sexual relationships that occurred between students and tutors or other people in power, particularly at Tiromoana. Helen Aiken remembered that she:

...found it really disconcerting to find there was a lot of sexual play, sexualised innuendo ... Part of that later 70s environment. I found this quite challenging. Real boundary breaches. Thing I found most uncomfortable. Turned people's lives upside down. Turned people's lives around, marriages that broke up (H. Aiken, personal communication, 22/01/14).

Karen Armstrong attended the first part of a training course at Tiromoana, but did not return for the second part due to the boundary violation that she witnessed between a person in power at the institution and a student: 
It just seemed like such a mixed message. My employer sends me to course where [xxxx] feels it's appropriate to have a relationship with someone on the course. We covered issues around power. I identified this as a misuse of his power. It tainted my experience of the course.... It crystalised to me the importance of having clear boundaries and being mindful of the use of power, with both colleagues and clients (K. Armstrong, personal communication, 14/01/14).

In discussions regarding this issue with various participants, there was a sense that many people knew that this sexual activity was going on. Some participants expressed that it was important to put these boundary violations in their historical contexts of the time, while others noted the fact that regardless of when they occurred they were still abuses of power. One academic described this idea of how these viewpoints could be held together:

We look at it now with 21st Century eyes. We are so aware of professional boundaries, and we look at relationships at work that can sometimes cause problems and in teams, especially between managers and staff.... We are much more sensitive about those things. In agencies people had relationships with people they supervised. It's not the same now. There was a sense that people knew it wasn't right or could be disruptive to relationships in teams. It would be a big deal now. With my 2IC hat it is because of power. Even relationships between participants, we don't know what the consequences were. It's interesting looking at where we have gone. Social workers now are so aware of these things... Where we were going, where we are going (Anonymous).

Another area that appeared to have some polarised views was that of how biculturalism was or was not addressed within the programmes. The experiences described below mostly came from Pakeha trainees.

\section{Te ao Māori}

The evolution of te ao Māori (Māori worldview) within these training institutes appeared to mirror what was occurring to a large extent within New Zealand society. In the beginning of Tiromoana, there did not appear to be much taught in terms of Māori content. Helen Aiken, who attended Tiromoana in 1977-78, recalled that they were the:

...days before cultural awareness. We did have a staunch Māori woman on the course. It was an eye opener to me, pretty foreign to me. It was not part of my awareness of that time. It was not really addressed in the course at that time (H. Aiken, personal communication, 22/01/14).

Ruth Manchester recounted that there were 'always two or three Māori Welfare Officers on the course. The differences were always there with you' (R. Manchester, personal communication 10/11/13). This is reiterated in Nash's PhD thesis in her interview with Tom Austin. She asked him about Māori content in the early years of Tiromoana and he responded:

At Tiromoana, we aimed at having three Māori Welfare Officers on each course. I don't remember if we achieved that, but I never wanted less than two. I became quite close friends with Bill Herewini who was in the 60s, Director of Māori Welfare, and his assistant Brownie Puriri. So this was a very close sort of relation... and apart from leading sessions on Māori Welfare they would often call in for an evening of informal discussions with students' (cited in Nash, 1998, p. 222).

Austin did, however, recount, 'It was very much a Pakeha oriented programme' (ibid, p. 223).

Other participants echoed the lack of attention to te ao Māori in the early 1980s at Tiromoana. One attendant, from 1983, claimed that: 
...the focus on cultural matters was very minimal. An expressed wish for the group to stay on a marae in the second part was not acted upon, instead we visited the Wellington Multi-Cultural Resource Centre and a marae, but this felt superficial. In general, a psychological rather than sociological focus was taken (Anonymous).

At Taranaki House, Joi Ellis who attended in 1978, remembered that there was material that had been very useful to her:

I came to NZ eight years or so prior to starting the course from the UK. The teaching around bicultural practice and understanding of the Treaty of Waitangi which had begun when I was at teachers' college and was advanced at Taranaki House (a marae stay for example) has been invaluable to me in my life in NZ and in my role as a social worker and I will always value that. Tanya Cumberland was an outstanding role model and leader. Looking back, it was a great catalyst to become an advocate for social justice (J. Ellis, personal communication, 8/01/14).

The Māori renaissance brought about great changes in both Tiromoana and Taranaki House programmes, with Directors of both programmes being committed to exploring racism and developing bicultural awareness. For many of the Pakeha participants, this appeared to be both a confronting and sometimes painful experience, but also a very valuable one. Māori trainers were brought in to run sessions for both programmes. One participant from Tiromoana remembered her experience of the training:

My other strong memory of the Tiromoana training was the treaty component. This was in the days when treaty was taught by confronting and it caused a huge divide amongst the group. Several of us stayed in the group and I remember how painful it was confronting my pakeha guilt for the first time. Some participants actually walked out though and from what I remember they felt picked on as pakeha (or feelings to that effect). I just remember there was a huge ruckus and I think a few of us tried to talk the others into coming back and apologising to the tutors but can't quite remember how it all ended (Anonymous).

Karen Armstrong also attended Tiromoana and she articulated the complex nature of the issues at the time:

What I was hit with was - not only was I Pakeha, I didn't know any Māori people personally. I came from a very white, rural district and had no experience or confidence in how to understand or relate to Māori.

...Puao te ata tu had just come out - for the first time I realised that not only were there cultural differences for Māori but, as Tangata Whenua, they had a special status and that it was my responsibility to understand and respect their culture and their rights under the Treaty of Waitangi. During my time at Tiromoana I felt there was a strong focus on Māori issues. I was very keen to learn all I could from the tutors and wanted to soak it all up, all the learning ... however at the time I really struggled with their approach.

We were told that we were going on a bus and we had to wear a skirt. When I asked where we were going, I was told to just 'experience' it. Deliberate non-engagement. This was a clear strategy. We didn't even know what we were going to or why we needed to wear a skirt.

It felt as if the tutors wanted to put us in the position of being out of our depth by throwing us on a bus and taking us to a marae without any indication of what the protocols were, how to behave to show our respect, how to greet our hosts in Māori, and so on. I felt mortified that I didn't know anything. At one level I understood what they were doing and, almost 30 years on, my vivid recollection of those feelings show what a powerful experience that was. 
However, as a trained teacher, I could not understand why they didn't then use that experience to educate us.... I learnt much from talking with other participants later on - perhaps that was their intention, but we never knew what their learning objectives were and it felt more like an experiment than planned teaching.

At this time there was a clear affirmative action programme on behalf of DSW. Quite a few participants were Māori, some of whom were only discovering and claiming their cultural identity. In the context of this residential course, with female Māori tutors, it felt cool to be Māori. I had never been on a marae let alone spent time with Māori before and yet the more time I spent around Māori, the more I admired and respected their culture, values and beliefs and the more I wished I could be Māori too (K. Armstrong, personal communication, 14/01/14).

Allyson Davys remembered her time as tutor at Taranaki House:

Titewhai Harawira was Kuia. We did a lot of work sessions with her, Ray and Mitzi Nairn... workshops around anti-racism... Marae visits . Lots of challenge around racism, anti racism. The WARAG group came out of Taranaki House (personal communication, 31/01/14).

The WARAG (Women Against Racism Action Group) Report (Berridge et al., 1984), explored racism occurring within the Department of Social Welfare within the Auckland area. The WARAG Report was not released by the DSW, but was leaked by members of the WARAG Community Consultation Group to the press, and was instrumental in the establishment of the Ministerial Advisory Committee on a Māori Perspective for the Department of Social Welfare in New Zealand chaired by John Rangihau (McClure, 2013). The subsequent report, Puao-te-ata tu (Ministerial Advisory Committee on a Māori Perspective for the Department of Social Welfare in New Zealand, 1988) was to become a seminal document in social work history in this country and was influential in such processes as the beginnings of a bicultural approach within the Department of Social Welfare and the initiation of family group conferencing.

Tanya Cumberland, who was Director at Taranaki House from 1978 to 1981, remembered that as tutors 'we were in a country with an indigenous people, many other cultures, and most of us were white middle class. They were quite tough experiences, some of those marae visits' (T. Cumberland, personal communication, 10/09/14).

Nicola Atwool was Director of Tiromoana House from the mid 1980s until it closed in 1988. She recalled that it was around the time of Puao te ata tu and it:

...changed the entire way we did things. We kept induction but made it a bicultural programme, and started caucusing... Māori caucus, Pakeha, then brought the group together. It was really challenging... They were amazing years really in terms of all the stuff that was going on. When we were challenged about how we were doing induction training, particularly in regards to our emphasis on biculturalism, we took Puao te ata tu as our mandate (N.Atwool, personal communication, 14/02/14).

The tradition of Māori involvement at Taranaki House continued when Graeme Harbutt took over directorship from Tanya Cumberland in 1985. Harbutt recalled that 'in my last year I got called to Wellington about why Titewhai ${ }^{4}$ was there stirring up at Taranaki House (G. Harbutt, personal communication, 31/01/2014).

Titewhai Harewira, a sometimes controversial Māori activist. 


\section{Experience of tutors}

For the most part, the tutors and directors who contributed to this research described their time at the institutions with fondness and as having been positive, but often not without its challenges. Many of the staff coming into the training programmes were pioneers, coming in without having had the benefit of attending social work training programmes or having training themselves in adult education and described sometimes feeling like they had been 'dropped in the deep end' (G. Harbutt, personal communication, 31/01/14).

Sometimes staff felt one step ahead of their students. Pascoe described the challenge of running some of the workshops for supervisors at Taranaki House in the 1980s. 'Supervisors were harder. People were more experienced than the tutors. It was challenging, but growth producing with people who were more experienced' (personal communication, 20/01/14).

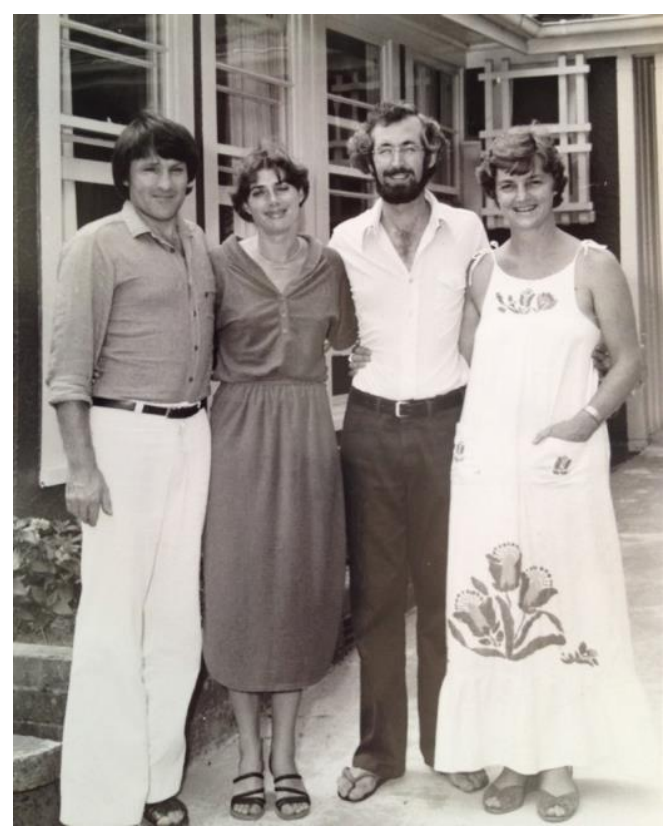

Taranaki House. Tutors (from left) : Graham Harbutt, Allyson Davys, John Crockett, Director: Tanya Cumberland, circa 1981

Pascoe illustrated some of the other aspects of working with students who had sometimes been made to attend. 'Some groups were 'good' groups to work with, some others had dynamics, people didn't want to be there, felt resentful about being there, taken away from home' (personal communication, 20/01/14).

Davys described how the experience of working at Taranaki House influenced her ongoing career in social work education:

It shaped views that I have about working as a team. Manager was inspiring, forward-thinking, developed us as a team. We were robust, encouraged honest feedback, supportive. One of the best career moves I had in terms of what I learnt. Working in a team and working with other people, started my love of education as an engaged rather than lecturing process, it was collaborative, interactive (personal communication, 31/01/14).

Cumberland described some of the tensions and challenges that she encountered. She, too, indicated a need to quickly acquire the skills of teaching adult learners with their diff needs. She also described, 'trying to make sure our training was related to life in the institutions and offi on the outside.' She remembered always questioning, 'what is social work and what are we training for?' They taught people on a continuum from individual counsellors to Māori Aff community workers whose work was all to do with whanau and community. It 'was an ongoing discussion and trial and error to get that balance right' (personal communication 10/09/14).

\section{Contributions made by the programmes to social work}

Many of the participants articulated the difference that the residential programmes had made to their practice. Some participants focused on the skills training aspect that they felt 
had been missing from other social work training that they later undertook (D. Burrowes, personal communication, 24/01/14).

Liz Beddoe, who attended Taranaki House, described how she:

...met people from other agencies. Focus on self in context, use of self in professional context. Don't think I learnt that about skills in my MA in social work. I learned other things, but basic skills came from Taranaki House (L. Beddoe, personal communication, 21/01/14).

Joi Ellis recalled one of the best aspects being:

The opportunity to train whilst employed and practising what was being taught at the time. Provided a lovely balance between being a student and being employed... I think the quality of the teaching stands out. I enjoyed the very practical nature of the course. Theory yes, but lots of opportunity to practise (personal communication, 8/01/14).

Similarly, Garry Cockburn who attended a Taranaki House Supervisor's workshop remembered the quality of teaching and the skills practice as being beneficial. 'The teaching team were quite integrated, great atmosphere, and material well presented and digestible. We were challenged doing role plays, live supervision' (personal communication, 14/02/14).

For some participants, Tiromoana or Taranaki House were just the beginning of their professional social work training, with many going on to further study. In 1973, Austin reported that:

In one respect, Tiromoana appears to have been too successful. A considerable number of social workers have been encouraged by their training experience here to apply for professional training on the diploma course. It is known that quite a proportion of them would not have contemplated this but for having come here. (p.5)

Many people appreciated the opportunity to train alongside social workers from other areas or fields of practice. Allyson Davys discussed some of the advantages around this:

It strikes me that organisations that now set up training only for themselves, rather than with other agencies lose this rich sharing of different perspectives and valuable networking. Training experiences are disadvantaged as we get siloed (personal communication, 31/01/14).

The networking and relationships formed through the training appeared to have been signifi in both short- and long-term periods for many people. Mary Farrelly observed that 'it was a very affi and enriching experience. The people I met, the discussions that were held both in and out of class time were important in shaping the early stages of my social work journey' (personal communication, 10/02/14). For others, the impact was long lasting, 'I know the social aspects were great. We had a lot of laughs; got to know each other really well and gained a lot of support from each other which carried on long after the training had fi (R. Instone, personal communication, 12/01/14). 'I made many collegial friendships that lasted for many years which was helpful for peer support' (J. Ellis, personal communication, 8/01/14).

\section{Golden times in social work}

Many of the respondents referred to the fact that Tiromoana and Taranaki House existed in a very different time in Aotearoa and social work history, and that looking back the experi- 
ence appeared to have been 'a real luxury' in terms of being supported to attend full-time training as part of one's induction. 'I am very grateful. I wouldn't have stayed in social work if I hadn't gone. A real foundation. Great doing it three months after I had started work' (S. Arnold, personal communication, 20/01/14).

One respondent described the value and commitment she felt was demonstrated to the profession of social work through these programmes:

Feel I am looking at it with rose tinted glasses from a long, long time ago. Thirty-five years ago. Era where social work was less siloed. Had instant network of people working in different agencies. DSW paid for it... health, probation. How much it would have cost! We got fed three meals a day and morning tea, costs, on salary. Massive investment in the profession (L. Beddoe, personal communication, 21/01/14).

Some participants referred to the shift of neo liberalism within society that changed the professional landscape of social work and social work training. Garry Cockburn described it as a time when 'there was heart and passion to the profession and belief that you could bring about some change. Now we are more bureaucratised and silenced, especially in the state sector. Now output-driven' (personal communication, 14/02/14). Mike Webster also echoed this sentiment:

This was well before new public management restructuring. Social workers were like a happy family, high esteem, esprit de corps. It felt like we were doing something significant with clients, common commitment to facilitate change. Ethos of those days has gone. Tiromoana days reinforced being part of a group of people who had been part of a common vision (personal communication, 29/01/14).

As a tutor and director of Taranaki House, Graeme Harbutt recalled that he felt mostly supported by Head Office:

It was the end of the period where agencies had connection with head office and politicians. Felt you were being heard. Felt that the Director General was on your side and client's side. There was a level of concern about supporting our clients....we were well supported (G. Harbutt , personal communication, 31/01/14).

Many respondents indicated that we could still benefit from training and institutions like Tiromoana and Taranaki House today. This relates to both the content and the process of the courses.

David Burrowes felt that there was:

...value in residential courses, time away from office, unlike online or based at office courses. Far too easy to get distracted and courses too short to have impact. Training was opportunity to have some time away from office as a way of achieving balance. We've lost track of that, about self care (Personal communication, 24/01/14).

Liz Beddoe stated that she remembered obtaining a solid grounding in personal and professional development:

Primarily what I remember was solid personal/professional development. Pretty present in first few years of my work. Our grads don't often get those things now. Learning good interpersonal skills keeps you safe as a practitioner, a good foundation can keep you safe over a career ... Wish we could get some of that back ... (L. Beddoe, personal communication, 21/01/14). 
Another respondent emphasised the gap that was filled by these courses. 'Best things? That it existed. In the vacuum that was there for social work education, brilliant that it was there, that people had vision to fund it' (A. Davys, personal communication, 31/01/14).

\section{Conclusion}

This article has attempted to paint a picture of some of the history and experiences of Tiromoana and Taranaki House Residential Training Centres. It has covered history, content of courses, some contentious issues, and memories of some of the people who worked and/ or attended the training programmes.

While one or two participants felt that the courses had not met their needs, what appears clear is that both training schemes played a valuable role in providing social work training through times where very little else was available. Both programmes were influenced by their times, to sometimes ill but more often beneficial effect. Many people believed that they represented a kinder and gentler time in social work where workers and their clients appeared to matter more.

The author would like to thank and acknowledge all the participants who gave freely of their time and knowledge in putting this article together.

\section{References}

Austin, T. (1973). Tiromoana. A survey in retrospect. The New Zealand Social Worker, 9(4), 3-7.

Beddoe, L. \& Randal, H. (1994). The New Zealand Association of Social Workers. The professional response to a decade of change. In R. Munford \& M. Nash (Eds.). Social work in action (pp. 21-36). Palmerston North, New Zealand: Dunmore Press.

Berridge, D., Cowan, L., Cumberland, T., Davys, A., McDowell, H., Morgan, J., Riley, L., Ruck, A., \& Wallis, P. (1984). Institutional racism in the Department of Social Welfare Tamaki-Makau-Rau. Auckland, New Zealand: Department of Social Welfare. Retrieved from: http://www.trc.org.nz/institutional-racism-department-social-welfare-auckland.

Cranna, J. (1989). Towards bicultural development: A history of the pioneering school of social work at the Auckland College of Education 1980-1988. Auckland, New Zealand: Auckland College of Education.

de la Roche, C. (1971). Many social workers. The New Zealand Nursing Journal, March, 1971, 17-18.

Government of New Zealand (n.d.). Communes and communities. From Centrepoint to eco-villages: 1980s-2000s. Te Ara Encyclopedia of New Zealand, p.3. Retrieved from: http://www.teara.govt.nz/en/communes-and-communities/page-3.

Johnston, M. (2001) Obituary: Betty Wark. New Zealand Herald, May 19th, 2001.

Manchester, B. (2008). A perspective on welfare. Notes on a social work and public service career in child care and protection with the young offender. 1954-1987. Unpublished manuscript.

Manchester, R. (1973). The present role of Tiromoana and possible directions for the future. The New Zealand Social Worker, 9(4), 7-13.

Mann, N. (1964). First course... at Tiromoana. The New Zealand Nursing Journal, May 1968, 13-14.

McClure, M. (2013). A civilised community: A history of social security in New Zealand 1898-1998. Auckland, New Zealand: Auckland University Press.

McCreary, J. (1971a). The school of science: Part one - The martians. The New Zealand Social Worker, 7(1), 9-17.

McCreary, J. (1971b). The school of science: Part two - The minions. The New Zealand Social Worker, 7(2),41-50.

Ministerial Advisory Committee on a Māori Perspective for the Department of Social Welfare in New Zealand (1988). Puao-Te-Ata-Tu (Day Break). The report of the Ministerial Advisory Committee on a Māori perspective for the Department of Social Welfare. Wellington, New Zealand: Department of Social Welfare.

Nash, M. (1998). People, policies and practice. Social work education in Aotearoa/New Zealand from 1949-1995. Unpublished doctoral dissertation, Massey University, Palmerston North, New Zealand.

Nash, M. (2001). Social work in Aotearoa New Zealand: Its origins and traditions. In M. Connolly (Ed.). Social work in New Zealand. Contexts of practice (pp 32-43). Auckland, New Zealand: Oxford University Press.

New Zealand Council for Educational Research. (1944). Training for social work. Report of an informal conference held on 18 \& 19 October, 1943. Wellington, New Zealand: Whitcombe and Tombs. 